\title{
Salmonid introduction in Patagonia: the ghost of past, present and future management
}

\author{
Patricio J. Macchi ${ }^{1, \bowtie} \&$ Pablo H. Vigliano ${ }^{1,2}$ \\ 1. Grupo de Evaluación y Manejo de Recursos Ícticos, Centro Regional Universitario Bariloche, Universidad Nacional del \\ Comahue, Bariloche, Argentina. 2. Instituto de Investigaciones en Biodiversidad y Medioambiente, Universidad Nacional del \\ Comahue, Consejo Nacional de Investigaciones Científicas y Técnicas, Bariloche, Argentina
}

\begin{abstract}
Aвstract. The present structure of the fish fauna of Patagonia has been influenced by natural processes and by the introduction of exotic fish with varying purposes. An analysis of the introductions between 1904 and 2011 in relation to 54 drainages showed that the differential success of salmonid species introduced into Patagonia is related to human actions, environment, evolutionary history and plasticity of the introduced species as well as to their abiotic and biotic interactions. Throughout time shifting policies have lacked clear goals and mandates, ultimately producing management actions and strategies rarely based on actual knowledge. In recent years two broad general management goals have emerged, conservation of native fish and economic growth through development of salmonid sport fisheries. Despite of the growing number of biological and ecological studies, there is a shortage of specific management studies. This is brought about in part because the different stake holders involved have partial views of the complexity of managing the resource and its fragility, and also due to their limited interaction. Only cooperation and concerted planning among interested parties may lead us to local and regional policies that take into account the above described goals. Thus, a key component for future management should combine research and management plans focused through greater cooperation among interested parties.
\end{abstract}

[Keywords: Salmo, Oncorhynchus, Salvelinus, Patagonia, invaders, policies, management]

Resumen. Introducción de Salmónidos en Patagonia: los fantasmas del manejo pasado, presente y futuro: La estructuración de la fauna de peces de Patagonia se ha visto influenciada por procesos naturales y por la introducción de especies exóticas con distintos propósitos. El análisis de la historia de las introducciones entre 1904 y el 2011 en relación a 54 cuencas de drenaje evidenció que el éxito de las mismas es dependiente de las acciones antrópicas, el ambiente, la historia evolutiva y la plasticidad de las especies introducidas, como así también de las interacciones ecológicas. A través del tiempo las políticas de introducción en Patagonia cambiaron sin que en apariencia existieran metas y mandatos claros, dando lugar a acciones y estrategias que raramente se basaron en una comprensión real de los problemas asociados. En los últimos años han surgido dos metas generales de manejo, la conservación de las especies nativas y el desarrollo económico mediante el progreso de pesquerías recreacionales. A pesar del número creciente de estudios biológicos y ecológicos, aún son escasos los estudios específicos de manejo. Esto es en parte el resultado de visiones parciales de las complejidades inherentes al manejo del recurso y su fragilidad, como de la escasa interacción y cooperación por parte de los distintos actores involucrados. La cooperación y planificación concertadas favorecerían la elaboración de políticas regionales y locales que tomen en consideración las metas descriptas anteriormente. Un componente clave para el manejo del recurso debería combinar planes focalizados de investigación y de manejo, y una mayor cooperación entre las partes interesadas.

[Palabras clave: Salmo, Oncorhynchus, Salvelinus, Patagonia, invasiones, políticas, manejo]

\section{INTRODUCTION}

Species introduction has been, after habitat loss, characterized as the second most important risk to maintain fish biodiversity on the planet (Allan \& Flecker 1993; Saunders et al. 2002). Introduction of species has generated problems in marine as well as in freshwater ecosystems (Helfman 2007). Direct consequences are the introduction of diseases (Hershberger et al. 2010), the degradation of native fish communities through competition and predation (McIntosh et al. 1992; Lydeard \& Belk 1993; Marchetti 1999; Penczack

patriciomacchi@yahoo.com.ar
1999; McIntosh 2000; Gratwicke \& Marshal 2001; Hrabik et al. 2001; Volpe et al. 2001), the impoverishment of autochthonous fish populations (Krueger \& May 1991; Blanco et al. 1998), the ecosystem deterioration (Fukushima et al. 1999; Donald et al. 2001; McDowall 2003; Simon \& Townsend 2003) and the disruption of ways of life and economic background related to the use of the natural resource (Ogutu-Ohwayo \& Hecky 1991; Witte et al. 1992). Despite all the consequences of introducing fish, this is still a common practice in all continents (Welcomme 1988).

Recibido: 4 de agosto de 2013; Fin de arbitraje: 16 de octubre; Última versión: 1 de abril de 2014; Aceptado: 8 de mayo. 
Kolar and Lodge (2001) proposed a conceptual model in which, a new species traverses through a series of stages in order to establish itself, generate a stable population and disperse. The probability of a species passing from one stage to the other is highly variable and appears to be species specific. In general, the success of animals and plants in establishing in a new region is correlated with the number of arriving propagules (i.e. propagule pressure) and with the frequency of arrivals (Duncan et al. 2003; Drake et al. 2005; Korsu \& Housko 2009).

The Salmonidae is the fish family most widely spread by humans (Welcomme 1988). Several salmonid species have been introduced for sport-fishing purposes, to increase fish diversity and, in the last decades, for aquaculture. Particularly, brown trout (Salmo trutta), rainbow trout (Oncorhynchus mykiss) and brook trout (Salvelinus fontinalis) are among the 12 more introduced species in over 30 countries (Welcomme 1992). The two first species are listed within the hundred more invasive of the planet (Lowe et al. 2004), and as two of the eight species with the highest establishment ratio in the countries where they have been introduced (Ruessink 2005). This rate of success is probably related with the role played by man as a transport vector (Colautti 2005).

The Patagonian icthyogeographical province belongs to the Austral sub-region of the Neotropical region (López \& Miquelarena 2005). This province extends from the Colorado River down to Tierra del Fuego and to the South of Puerto Montt in Chile. The Austral sub-region is characterized by low specific diversity (Baigún \& Ferriz 2003; Pascual et al. 2007) contrasting with the rest of the Neotropical region (Ringuelet 1975). The fish fauna of Patagonia includes 17 species of Neotropical and circumpolar origin and has a significant number of endemisms (Arratia et al. 1983). The structure of the fish fauna of the region has been influenced by several factors including geological processes (e.g. Gondwana separation, rising of the Andes, volcanism), climatic processes (e.g. glaciations, global climate change), biotic interactions and human activities (e.g. introduction and dispersion of species, landscape changes, etc.) (Pascual et al. 2007).

Even though the initial freshwater fish introductions in Argentina started during the XIX century, the first official introduction took place in 1904 (Baigún \& Quirós 1985). Since then, a total of 21 species have been imported from different parts of the world (López 2001), 11 of these species having self supporting populations across the country. This represents $2.4 \%$ of the total freshwater fish fauna, which is a low number compared with the situation in other countries (Welcomme 1988; Bianco 1998; Elvira \& Almodovar 2001), where introduced species outnumber autochthonous ones. A total of 11 imported fish species and 2 species from the Paranoplatense region were introduced in the Patagonian province (Pascual et al. 2002). Of the 13 species introduced, 10 belong to the Salmonidae and the rest to the Atherinopsidae (Odonthestes bonariensis), Cyprinidae (Cyprinus carpio) and Callichthydae (Corydoras sp.). The proportion of introduced to native species in the Patagonian region is higher than in the rest of the country, with exotic species comprising up to $43 \%$ of the total freshwater fish fauna.

The research on the impact of introduced species upon the native fauna can be considered in its beginnings. Unfortunately, there is a lack of studies prior to the introductions that could set the starting point to track the effect of this practice in Patagonia (Pascual et al. 2002; 2007). According to Cussac etal. (2012), in Argentinean and Chilean Patagonia the introduction of salmonids has caused distributional changes of the native fauna, negative shifts in native fish abundance due to predation, competition, and changes in trophic webs, among others. However, the extent of these effects has not been sufficiently assessed.

The introduction of salmonids on the different basins of Patagonia has been a long and complex process, characterized by repetitive stocking of several species in water bodies of the region. We believe that changes throughout time in the stocking practices in Patagonia were the result of prevailing shifting views and perceptions.

The present paper aims to analyze the history of salmonid introductions in Patagonia and to discuss the strategies of stocking and management applied in order to gain better understanding of their actual distribution and success as invaders. This type of knowledge is necessary to design management policies that may help balancing the seemingly contrasting goals of native fauna conservation and the growth of salmonid sport fishing. 


\section{Materials And Methods}

\section{Study Area}

Argentinean and Chilean Patagonia cover an area of $1,400,000 \mathrm{~km}^{2}$ (Pascual et al. 2007). This region has a complex hidrography with water drainages extending from the Andes to the Atlantic or to the Pacific oceans as well as an extensive number of endorheic ponds and rivers (De Aparicio \& Difrieri 1958). Atlantic drainages have their head waters on the Andes and extend to the East forming complex networks of water bodies, including rivers and large oligotrophic lakes in their upper sections. The middle and lower sections receive few tributaries while they traverse the Patagonian steppe in their way to the sea (López 2001). Pacific drainages are born on both sides of the Andes, those originated on the western slopes have direct courses to the Pacific. Whereas, those born on the eastern slopes initially flow towards the East and later to the West crossing the Andes into Chilean territory to finally drain into the Pacific (Lopez 2001).

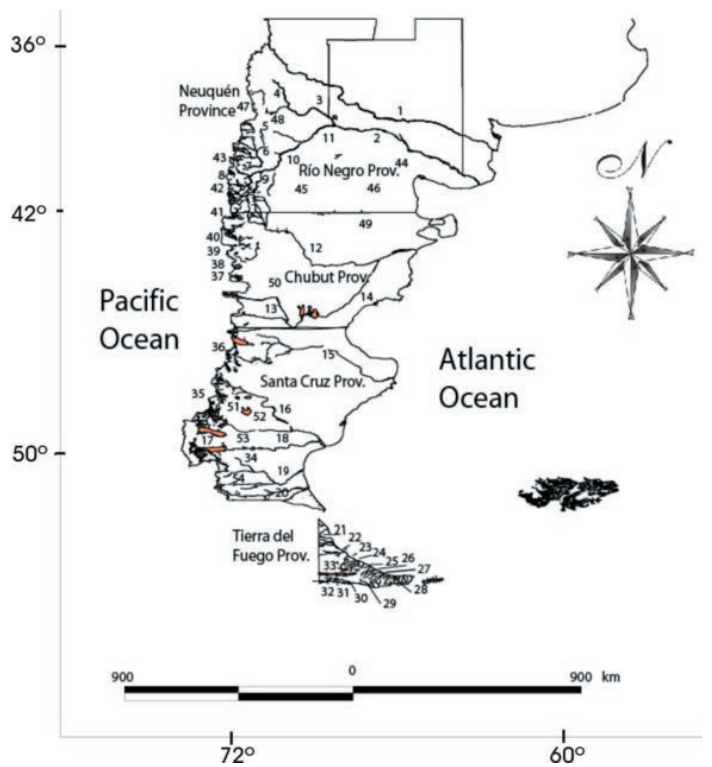

Figure 1. Basins and Sub-basins included in the database of this investigation.

Figura 1. Cuencas y sub-cuencas incluidas en la base de datos de esta investigación

Atlantic drainage basins: 1. Colorado, 2. Negro, 3. Lower Neuquén, 4. Higher Neuquén Headwaters, 5. Aluminé, 6.Collón Cura, 7. Traful, 8. Nahuel Huapi, 9. Higher Limay, 10. Middle Limay, 11. Lower Limay, 12. Chubut, 13. Senguer, 14. Chico, 15. Deseado, 16. Burmeisteir-Chico, 17. Higher Santa Cruz, 18. Lower Santa Cruz, 19. Coyle, 20. Gallego, 21. San Martín, 22. Grande, 23. Fuego, 24. Ewan, 25. San Pablo, 26. Lainez, 27. Irigoyen, 28. Bueno, 29. Moat, 30. Pipo, 31. Oliva, 32. Roca.Pacific drainage basins: 33. Fagnano, 34. Vizcacha, 35. Pascua, 36. Baker, 37. Simpson, 38. Pico, 39. Corcovado, 40. Futaleufú, 41. Puelo, 42. Manso, 43. Lacar. Endorheic basins: 44. Valcheta, 45. Maquinchao, 46. Unco-Juncal, 47. Chanquin, 48. Blanca, 49. GanGan, 50. Salina, 51. Cardiel, 52. Strobel, 53. La Laurita, 54. Huergo.
Table 1. Official archives (National Bureau of Agriculture, Livestock and Fisheries of Argentina) that were consulted to build the database of salmonid introductions in Patagonia.

Tabla 1. Archivos oficiales (Ministerio de Agricultura, Ganadería y Pesca de la Nación Argentina) que fueron consultados para construir la base de datos de la introducción de salmónidos en la Patagonia.

\begin{tabular}{|c|c|c|}
\hline & Record Type & Period \\
\hline \multirow[t]{2}{*}{ Nahuel Huapi Fish Farm } & & 1908-1933 \\
\hline & Registry book & 1914-1917 \\
\hline \multirow[t]{2}{*}{ Bariloche Fish Farm } & $\begin{array}{l}\text { Reports and } \\
\text { correspondence }\end{array}$ & 1934-1970 \\
\hline & $\begin{array}{l}\text { Work done, } \\
\text { monthly summary }\end{array}$ & 1939-1942 \\
\hline Río Limay Fishfarm & $\begin{array}{l}\text { Records of fish } \\
\text { stocking }\end{array}$ & 1950-1979 \\
\hline $\begin{array}{l}\text { Centro de Salmonicultura } \\
\text { Bariloche }\end{array}$ & $\begin{array}{l}\text { Reports and } \\
\text { correspondence }\end{array}$ & 1971-1994 \\
\hline $\begin{array}{l}\text { Official archives National } \\
\text { Bureau of Agriculture, } \\
\text { Livestock and Fisheries of } \\
\text { Argentina }\end{array}$ & $\begin{array}{l}\text { Fish stocking } \\
\text { records }\end{array}$ & 1938-1979 \\
\hline
\end{tabular}

In this paper the analysis of salmonid introductions was addressed at a regional scale without considering heterogeneity between and within drainage basins. For this analysis we have considered almost all the major drainages, Pacific and Atlantic, and a number of endorheic ones. The hydrological network considered includes 54 drainages and sub-drainages (Figure 1) located in five Argentinean provinces included in the Patagonian region, 32 draining into the Atlantic, 11 into the Pacific and 11 endorheic (Figure 1). All the Pacific basins considered and those of the Gallegos and Grande rivers which drain to the Atlantic are shared between Argentina and Chile.

\section{Data gathering and analysis}

For this paper we built up a data base covering the period 1904-2011, that compiles information from a wide variety of sources, including historical archives of hatcheries and sport fishing associations, registry books, grey literature and records from our research projects since 1996 up to date.

\section{Historical analysis}

Official archives were consulted to build the database of salmonid introductions in Patagonia, most of them belonging to the National Bureau of Agriculture, Livestock and Fisheries of Argentina and related institutions (Table 1). Also, the analysis included data from published work from different national and provincial organizations (Marini 1934; Gonzales Regalado 1945; Bruno Videla 1978; Baigún \& Quirós 1986; Casalinuovo et al. 2002; Dirección de Pesca Continental 2011). A data base was created including 283 water bodies, 1867 stocking records of each introduced species, its stocking date, site and basin. Due to the fact that stocking density varied between regions, stocked water bodies 
Table 2. Salmonid species $(\mathrm{Y})$ and date of their first introduction (between brackets) into Patagonian basins. (ND) date of introduction not available. Omi: O. mykiss, Sf: S. fontinalis, Ss: S.salar, St: S.trutta, Sn: S.namaycush, Ot: O. tshawytscha, On: O.nerka, Oma: O.masou, Cor: C. clupeaformis, Ok: O. kitsuch.

Tabla 2. Especies de salmónidos introducida $(Y)$ y fecha de su primera introducción (entre paréntesis) en las cuencas patagónicas. (ND) fecha de primera introducción no disponible. Ver detalles en la leyenda en inglés.

\begin{tabular}{|c|c|c|c|c|c|c|c|c|c|c|c|}
\hline Basin & Sub-basin & Omi & Sf & Ss & St & Sn & Ot & On & Oma & Cor & Ok \\
\hline \multicolumn{12}{|c|}{ Atlantic Drainage } \\
\hline Colorado & Colorado & Y (1926) & & & Y (ND) & & & & & & \\
\hline \multirow[t]{10}{*}{ Negro } & Negro & $Y(N D)$ & $\mathrm{Y}(\mathrm{ND})$ & & $\mathrm{Y}(\mathrm{ND})$ & & & & & & \\
\hline & Neuquén Higher. & Y (1945) & Y (1945) & & Y (1945) & & & & & & \\
\hline & Neuquén Lower & Y (1923) & Y (1924) & & & & & & & & \\
\hline & Aluminé & $\mathrm{Y}(\mathrm{ND})$ & Y (1939) & $\mathrm{Y}(\mathrm{ND})$ & $\mathrm{Y}(\mathrm{ND})$ & & & & & & \\
\hline & Collón Curá & Y (1941) & Y (1937) & Y (1937) & Y (1946) & & & & & & \\
\hline & Traful & Y (1932) & Y (1904) & Y (1904) & Y (1931) & Y (1904) & & & & Y (1904) & \\
\hline & Nahuel Huapi & Y (1928) & Y (1904) & Y (1904) & Y (1931) & Y (1904) & & & & Y (1904) & \\
\hline & Limay Higher & Y (1928) & $Y(1904)$ & Y (1904) & Y (1931) & & & & & & \\
\hline & Limay Middle & Y (1931) & Y (1909) & Y (1931) & Y (1931) & & & & & & \\
\hline & Limay Lower & Y (1924) & Y (1923) & & $\mathrm{Y}(\mathrm{ND})$ & & & & & & \\
\hline \multirow[t]{3}{*}{ Chubut } & Chubut & Y (1931) & Y (1910) & Y (1931) & Y (1965) & & & & & & \\
\hline & Senguer & Y (1942) & Y (1942) & Y (1942) & $\mathrm{Y}(\mathrm{ND})$ & & & & & & \\
\hline & Chico (Ch) & Y (1942) & Y (1942) & Y (1942) & & & & & & & \\
\hline Deseado & Deseado & Y (1914) & & & & & & & & & \\
\hline Chico & Burmeister/Chico & Y (1909) & Y (1909) & Y (1909) & & Y (1909) & Y (1909) & & & & Y (1909) \\
\hline \multirow[t]{2}{*}{ Santa Cruz } & S. Cruz Higher & Y (1908) & Y (1908) & & & Y (1908) & & Y (1908) & & & \\
\hline & S. Cruz Lower & Y (1908) & $\mathrm{Y}(\mathrm{ND})$ & Y (1909) & Y (1909) & Y (1909) & Y (1908) & Y (1909) & & & Y (1909) \\
\hline Coyle & Coyle & $\mathrm{Y}(\mathrm{ND})$ & $\mathrm{Y}(\mathrm{ND})$ & & $\mathrm{Y}(\mathrm{ND})$ & & & & & & \\
\hline Gallego & Gallego & $Y(N D)$ & Y (1908) & & Y (1937) & Y (1908) & Y (1909) & Y (1908) & & & \\
\hline San Martin & San Martín & Y (1936) & & & Y (1937) & & & & & & \\
\hline Grande & Grande & Y (1935) & Y (1931) & Y (1936) & Y (1937) & & & & & & \\
\hline Fuego & Fuego & Y (1935) & & & Y (1935) & & & & & & \\
\hline Ewan & Ewan & Y (1935) & Y (1935) & & Y (1935) & & & & & & \\
\hline San Pablo & San Pablo & Y (1968) & Y (1968) & & Y (1968) & & & & & & \\
\hline Lainez & Lainez & $\mathrm{Y}(\mathrm{ND})$ & & & $\mathrm{Y}(\mathrm{ND})$ & & & & & & \\
\hline Irigoyen & Irigoyen & $\mathrm{Y}(\mathrm{ND})$ & & & $\mathrm{Y}(\mathrm{ND})$ & & & & & & \\
\hline Bueno & Bueno & $\mathrm{Y}(\mathrm{ND})$ & & & $\mathrm{Y}(\mathrm{ND})$ & & & & & & \\
\hline Moat & Moat & $\mathrm{Y}(\mathrm{ND})$ & & & $\mathrm{Y}(\mathrm{ND})$ & & & & & & \\
\hline Olivia & Olivia & Y (1944) & Y (1944) & Y (1945) & $Y(N D)$ & & & & & & \\
\hline Roca (TF) & Roca & $Y(N D)$ & & & $\mathrm{Y}(\mathrm{ND})$ & & & & & & \\
\hline \multicolumn{12}{|c|}{ Pacific Drainage } \\
\hline Valdivia & Lacar & Y (1931) & Y (1931) & Y (1938) & Y (1931) & & & & & & \\
\hline \multirow[t]{2}{*}{ Puelo } & Puelo & Y (1941) & Y (1920) & Y (1941) & Y (1968) & & & & & & \\
\hline & Manso & Y (1938) & Y (1916) & Y (1931) & Y (1931) & & & & & & \\
\hline Futaleufú & Futaleufú & Y (1942) & Y (1959) & Y (1942) & Y (1942) & & & & & & \\
\hline \multirow[t]{2}{*}{ Palena } & Corcovado & Y (1939) & Y (1920) & Y (1939) & & & & & & & \\
\hline & Pico & Y (1965) & Y (1965) & Y (1962) & & & & & & & \\
\hline Simpson & Simpson & & & & & & & & & & \\
\hline Baker & Bs As/Puyrr. & Y (ND) & $\mathrm{Y}(\mathrm{ND})$ & $\mathrm{Y}(\mathrm{ND})$ & $Y(\mathrm{ND})$ & & & & Y (1983) & & \\
\hline Pascua & S. Martín/Bel. & & Y (1908) & Y (1964) & & & & & & & \\
\hline Vizcacha & Vizcacha & $Y(N D)$ & & & $\mathrm{Y}(\mathrm{ND})$ & & & & & & \\
\hline Fagnano & Fagnano & Y (1935) & Y (1934) & Y (1945) & Y (1935) & & & & & & \\
\hline
\end{tabular}

were grouped into basins and sub-basins (Figure 1 ). Due to the fact that all available records of numbers stocked by basins are incomplete, the number of basins and sub-basins where each species was introduced was used as a proxy of propagule pressure.
As a measure of success of the introduction in each basin or sub-basin, the occurrence of a given species according to the literature and/or to recent samplings was considered. We assumed that the occurrence of a species in one water body implies its presence in the whole basin or sub-basin. 


\section{RESULTS}

\section{Analysis of salmonid introduction}

The landscape of salmonid introductions in Patagonia is complex due to the fact that rivers draining to the Pacific ocean could have been stocked from Argentina and also from Chile (Bruno Videla 1938). As an example salmonids may occur in basins for which no records of Argentinean introductions are available (Table 2). During the entire period considered, 10 salmonid species were introduced to Argentina (Tables 2 \& 3). The effects of these introductions varied greatly between basins which may apparently, relate with the species and the pressure of the introduction. A large number of species were introduced in the sub-basins of the Traful river and the Nahuel Huapi lake $(\mathrm{N}=6)$, as well as in the basins of the rivers Chico $(\mathrm{N}=6)$, Santa Cruz $(\mathrm{N}=8)$ and Gallego $(\mathrm{N}=6)$, all draining to the Atlantic. The only Pacific drainage in which 5 salmonid species were introduced is that of the Baker River, including lakes Buenos Aires and Pueyrredon sub-basins. There is no certainty about the origin of these species due to the lack of national records regarding their introduction. The only reference available corresponds to the introduction of $O$. masou (cherry salmon) from Chile in lake Buenos Aires (Table 2). In the remaining sub-basins varying numbers of species (i.e. O. mykiss, $S$. trutta, S. fontinalis and S. salar (Atlantic salmon) were introduced. On most endorheic basins $O$. mykiss and S. fontinalis were introduced (Table 3). Basins with the highest number of introductions have two common features: imost of the species introduced were brought into the country between 1904 and 1910, and, ii- the systems were close to the reception centers created in 1904.

Most of the introduced species were released during the first 6 years of the time period 19041991 (Table 4). During this stage, 8 species were introduced in Southern Patagonia and 4 in Northern Patagonia (Tables 2 \& 3). Of them, S. fontinalis, S. namaycush (lake trout) and S. salar were stocked in both areas. In Northern Patagonia all three species were introduced into 6 drainages, whereas in Southern Patagonia O. mykiss was introduced in the Deseado river (Table 2 \& 4). Starting in the 1930's the only species introduced to new basins or restocked in Patagonia were O. mykiss, S. fontinalis, S. salar and S. trutta.
Table 3. Salmonid species $(\mathrm{Y})$ and date of first introduction (between brackets) in Patagonian endorheic basins. Omi: O. mykiss, Sf: S. fontinalis, St: S. trutta.

Tabla 3. Especies de salmónidos introducida $(Y)$ y fecha de primera introducción (entre paréntesis) en las cuencas endorreicas de la Patagonia. Ver detalles en la leyenda en inglés.

\begin{tabular}{lccc}
\hline Basin/Pond & Omi & Sf & St \\
\hline Valcheta & Y (1928) & Y (1928) & \\
Maquinchao & Y (1960) & Y (1942) & \\
Unco & Y (1967) & & \\
Juncal & & Y (1967) & \\
Chanquin & Y (1967) & & \\
Blanca & Y (1965) & Y (1965) & Y (1965) \\
GanGan & Y (1943) & Y (1972) & \\
Salina & Y (1943) & Y (1943) & \\
Cardiel & Y (1943) & Y (1943) & Y (1977) \\
Strobel & Y (1976) & Y(1964) & \\
Huergo & Y (1978) & & \\
La Laurita & Y (1978) & & \\
\hline
\end{tabular}

Towards the end of the 1960's almost all subdrainage basins had been stocked with at least one salmonid species (Tables $2 \& 3$ ). Later, in 1983, O. masou was introduced from Chile into Lake Buenos Aires (Table 4).

The species more highly stocked from 1904 up to this date are O. mykiss $(96.4 \%$ of all basins and sub-basins), S. fontinalis (72.7 $\%)$, S. trutta $(67.3 \%)$ and S. salar $(41,8 \%)$ (Table 4). Salvelinus namaycush, stocked with comparatively less effort, was brought into several Northern and Southern Patagonian drainages ( $11 \%$ of basins and sub-basins). In the Nahuel Huapi sub-basin, the introduction of $S$. namaykcush was performed in the 1940's without success. Also, two attempts of introducing Coregonus clupeaformis (lake whitefish) were done in 1937 and 1962.

The analysis of the relationship between the number of basins originally stocked and the number of basins were the presence of the different species has been confirmed, showed that O. mykiss and S. trutta occur in $85 \%$ and $97 \%$ of the lake basins, respectively (Table 4). The same analysis revealed that the success of S. namaycush can also be considered high (50 $\%$ ) when pooling all the basins of Patagonia where it was introduced, and, very high (75\%) if only southern Patagonian drainages are considered (Table 4). Salvelinus fontinalis had a relatively lower success, being recorded in 17 basins $(42.5 \%)$ and sub-basins where it was introduced (Table4). According to the available records of this species in Northern Patagonia, it apparently had a wider distribution until 
the 1940 's, occurring in $100 \%$ of the Negro, Limay and Chubut river basins. Nowadays, S. fontinalis is found only in the headwaters of these rivers. Salmo salar prospered only in a few basins $(30.4 \%)$ despite a considerable effort to introduce it in several Patagonian drainages (Table 4). Of all the stocked salmonid species, O. tshawytscha (chinook salmon) and O. kitsuch (coho salmon) can be considered special cases. This is due to the fact that introductions from Argentina were point events (Table 4) and because their present distributions do not necessarily coincide with that of the original populations, being likely the result of recent invasions originated by escapes from fish farms in Chile.

\section{Historical shift of goals}

According to Vallete (1924) the major objectives behind fish introduction policy applied to Patagonia from 1904 were to increase the diversity of the fish fauna and to create fisheries with species of high economic or sport value. For this purpose two hatcheries were built to support the introductions. The Nahuel Huapi salmonid hatchery (19041931) was installed on the Limay River and dedicated to the introduction and distribution of salmonids in northern Patagonia. A second hatchery was built on the shores of the Santa Cruz River (1904-1913) to contribute to the introductions in Southern Patagonia (Marini
1934). After this initial period, the introduction practices declined for 15 years; the Southern hatchery closed and the Northern one limited its activity to introducing $S$. fontinalis (Marini 1934). Around this period, the first fishing regulations established fishing seasons and zones and the regulation of commercial fishing for the Nahuel Huapi region (Marini 1944).

From 1931 to 1970 objectives became broader and actions to generate and develop multispecific sport and commercial fisheries were put into practice. Fishing regulations became broader in terms of species, fishing season and sites (Marini 1944), new species were introduced and salmonids as well as native species were re-stocked. Starting in 1934, the National Park Administration played a central role in managing the resource, fostering sport fisheries and sportfishing tourism within its jurisdiction. Thus, in 1932 the original hatchery was relocated and transformed into a larger facility the "Bariloche fish farm" ("Piscicultura Bariloche") that became the "Bariloche Salmonid Farming Centre" ("Centro deSalmonicultura Bariloche") in 1971, closing in 1994. In 1942 another facility was installed, the Limay River Fish Farming Station ("Estación de Piscicultura Río Limay"), mostly dedicated to the introduction and distribution of Odontesthes hatcheri (Patagonian silverside) and Percichthys trucha (creole perch). This fish farm belongs nowadays to Neuquén province.

Table 4. Number of basins and sub-basins where salmonid species were introduced grouped by decade from1904-1991 into Northern Patagonia (PN; provinces of Neuquén, Río Negro and Chubut) and Southern Patagonia (PS; Santa Cruz and Tierra del Fuego). Omi: O. mykiss, Sf: S. fontinalis, Ss: S. salar, St: S. trutta, Sn: S. namaycush, Ot: O. tshawytscha, On: O. nerka, Oma: O. masou, Cor: C. clupeaformis, Ok: O. kitsuch. \#T:Total number of basins where a species was introduced(our own data), \#P: number of basin/sub-basins where a species is present (Pascual et al. 2002, Vigliano \& Alonso 2007, Aigo et al. 2008, Habit et al. 2012 and our own data).

Tabla 4. Número de cuencas y subcuencas donde se introdujeron especies de salmónidos agrupados por década (1904-1991) en la Patagonia Norte (PN; provincias de Neuquén, Río Negro y Chubut) y Patagonia Sur (PS; Santa Cruz y Tierra del Fuego). Ver detalles en la leyenda en inglés.

\begin{tabular}{|c|c|c|c|c|c|c|c|c|c|c|c|c|c|c|c|c|c|c|c|c|}
\hline & \multicolumn{2}{|c|}{ Omi } & \multicolumn{2}{|c|}{ Sf } & \multicolumn{2}{|c|}{ Ss } & \multicolumn{2}{|c|}{ St } & \multicolumn{2}{|c|}{ Sn } & \multicolumn{2}{|c|}{$\mathrm{Ot}$} & \multicolumn{2}{|c|}{ On } & \multicolumn{2}{|c|}{ Oma } & \multicolumn{2}{|c|}{ Cor } & \multicolumn{2}{|c|}{ Ok } \\
\hline & $\mathrm{PN}$ & PS & PN & PS & PN & PS & $\mathrm{PN}$ & PS & $\mathrm{PN}$ & PS & PN & PS & PN & PS & PN & PS & $\mathrm{PN}$ & PS & $\mathrm{PN}$ & PS \\
\hline 1904-1910 & & 3 & 5 & 4 & 3 & 2 & & 1 & 2 & 4 & & 3 & & 3 & & & 2 & & & 2 \\
\hline $1911-1920$ & & 1 & 3 & & & & & & & & & & & & & & & & & \\
\hline 1921-1930 & 6 & & 3 & & & & & & & & & & & & & & & & & \\
\hline 1931-1940 & 5 & 6 & 3 & 3 & 6 & 1 & 6 & 6 & & & & & & & & & & & & \\
\hline 1941-1950 & 7 & 3 & 5 & 3 & 4 & 3 & 3 & & & & & & & & & & & & & \\
\hline $1951-1960$ & 1 & & 1 & & & & & & & & & & & & & & & & & \\
\hline 1961-1970 & 4 & 1 & 3 & 2 & 1 & 1 & 3 & 1 & & & & & & & & & & & & \\
\hline 1971-1980 & & 3 & 1 & & & & & 1 & & & & & & & & & & & & \\
\hline$>1980$ & & & & & 1 & & & & & & & & & & & 1 & & & & \\
\hline Sin fecha & 2 & 10 & 1 & 3 & & 1 & 5 & 10 & & & & & & & & & & & & \\
\hline \#T & & & & 40 & & 3 & & & & 6 & & 3 & & 3 & & & & 2 & & 2 \\
\hline \#P & 4 & & & 19 & & 7 & 3 & & & 3 & & 0 & & - & & & & - & & 2 \\
\hline
\end{tabular}


From 1970 onwards a slow process of change could be noted, salmonids were restocked and the fish farm at Bariloche started promoting aquaculture for commercial purpose in the region. With this goal in mind, commercial varieties of rainbow trout were imported into the country, and genetic selection through breeding was performed (Baiz 1984). Towards the end of the 1970's and beginning of the 1980's each Patagonian province had its own hatchery and the management decisions were decentralized. Provincial management was geared towards the development of sport fisheries and, until recently, the introduction of salmonids into new water bodies was a common practice (Dirección de Pesca Continental 2011). At the same time, the management policies of the National Park Administration shifted towards the protection of native species, thereby opposing to new introductions of exotic species (Pascual et al. 2007). Later in the 1980's, with the establishment in the region of scientific research groups, several studies with broader objectives were undertaken as well as the interaction with management agencies. During the 90's, the provincial governments of Patagonia and the National Park Administration integrated into an interjurisdictional board to handle management issues, fishing regulations and licenses for shared jurisdictions. Nowadays, each province and park retain the right to issue the policies in environments of their exclusive jurisdictions.

It is worth to note that despite official policies there are no clear mandates for the different organizations involved in the management of the resource. In general terms and with only few exceptions, no previous studies, estimations of carrying capacities, monitoring of introduction, or re-stocking analyses have been conducted. The most complete historical assessment available was performed between 1930 and 1940 in the Limay, Manso and Futaleufú drainage basins, aiming to record the specific composition of the fish assemblages and to determine which species to introduce or stock (Bruno Videla 1938;1941;1944; Gonzalez Regalado 1941 a;b;c; 1945).

\section{DisCUSSION}

Introduction and spread of exotic species in Patagonia has been a long process that continues to this day (Macchi et al. 2008).
In Argentina 10 species of salmonids were introduced with varying degrees of success. Only O. nerka and C. clupeaformis could not adapt to the new environments. Of the 8 remaining species, some adapted rapidly and prospered, whereas others established successfully recently through introgressions from Chile (Correa \& Gross 2007).

Salmonid capacity to invade seems to be related to a combination of factors that range from zoogeography of their place of origin, their evolutionary history, environmental resistance throughout their life history (Fauch 2008), and biotic interactions (Korsu et al. 2007). For invasive species the success or failure to adapt to a new site is highly context dependent. The differential success of salmonid introductions and the present structure of freshwater fish communities in Patagonia is apparently related to several factors such as the effort applied by managers, the availability of species propagules, the transport facilities and accessibility to water bodies, as well as to species plasticity, interactions among exotic and native species, and connectivity between water bodies. Initially Salvelinus fontinalis dispersed widely and was successful in most Northern Patagonian drainages. Nowadays, this species experiences retraction seemingly due to the increase in the stocking of $O$. mykiss and S. trutta (Macchi et al. 2008). The first of these two species prospered in most of the examined drainages and adapted to a variety of environmental and trophic conditions (Juncos et al. 2011). S. trutta, also considered an adaptable species (Young et al. 2010), prospered in most drainages despite its stocking was less intensive, becoming the top predator (Macchi et al. 1999). On the other hand, the considerable effort applied to introduce $S$. salar in numerous water bodies had relatively lower success, having been reported only in 7 of the 23 drainages where it was introduced. The low success of this species in Patagonia could be attributed to several causes. Valiente et al. (2010) stated that brown trout introduced in Patagonia tends to displace the Atlantic salmon.

S. namaycush, introduced in small numbers between 1904 and 1910, constitutes an interesting case because it did not prosper in Northern Patagonia, but was successful in 3 of the 4 drainages in which it was introduced in Southern Patagonia. This could indicate a key environmental factor that regulates the invasive capacity of this species. 
Another failed introductions were those of O. tshawytscha and O. kisutch at the beginning of the century (Thompson 1940; Vigliano \& Alonso 2007). During the 1980's the occurrence of king salmon was reported in the Pacific drainages of the Corcovado and Pico rivers (Wergzyn \& Ortubay 2009). Today this species occurs in at least 10 drainages of the 54 included in the present analysis. The expansion of its distributional range in Patagonia is considered to be the result of escapes from Chilean fish farms, ranching in the 1970's-1980's and to the straying of established populations (Correa \& Gross 2007; Soto et al. 2007; Pascual et al. 2009; Riva Rossi et al. 2012). Oncorhynchus kitsuch could have experienced a similar history, occurring at present in a few Pacific drainages retreats (Wergzyn \& Ortubay 2009).

The analysis of the official policies for freshwater fish fauna of Argentina is difficult due to the lack of historical records of goals and objectives of introductions. Introductions to develop sport and economic fisheries as indicated by Vallete (1922) hardly justify the logistic and economic cost associated. First, tourism was not a major economic activity in Patagonia at the beginning of the century (Bessera 2006). Further, boosting commercial fishing did not seem profitable due to the fact that the population of Patagonia at this time was so scarce and scattered that the region was considered practically uninhabited (Willis 1988). Moreover, the long distances among populations and the available transportation did not allow sending fish products to far away markets. It seems likely that introductions were part of broader policies with long term goals for the national territories recently occupied by the argentine government (Willis 1988). The introduction of numerous terrestrial vertebrate species between the XVIII and XIX centuries (Novillo \& Ojeda 2008) seems to indicate a perception of Patagonia as a region of low diversity and the general belief in the need of increasing it. As stated until the 1970's, policies seem to emphasize the development of recreational and commercial fisheries. This period constitutes the ghost of past introductions, with no clear goals, diffuse and rather inconsistent actions, nor plans or systematized research to ensure a true understanding of the needs, limitations, and problems associated with this practice. In the 1970's the management of the freshwater resources was decentralized from the national government towards the provincial governments and the National Park Administration (Macchi et al. 2008). Concomitantly, there was an increase in the perception that salmonids could become a local and regional economic driving force in relation to the added value of sport fishing related tourism (Pascual et al. 2007), which led to two management imperatives. One related to conservation of native species generally associated with NGO's and the National Park Administration, and the other related to the potential economic development associated to the salmonid sport fisheries of local and provincial interest. Both aspects constitute the ghost of the present, salmonids being perceived both as invaders and as a resource, while involved parties are still reluctant to consider that as the sides of the same coin. At this stage, management requires cooperation and interaction between interested parties to be effective. In this scenario we can add that the past 20 years have seen an increase in the number of specific environmental studies and research on the ecology of fish populations and communities. We should also consider that despite national and provincial laws concerning introduction, transport and culture of fish species (Pascual et al. 2007), enforcement is at best deficient, and there is still a shortage of studies and projects addressing specific management issues. This is partly due to the fact that the interaction between general public, research groups and administrators is still weak and, that many of the involved parties ignore the complexity of the management and the fragility of the resource. Managing fish resources is complex because it involves not only the environment and the fish but also a human component (Krueguer \& Decjker 1999).

Even though we cannot do much about the past, the ghost of future management shows us two potential scenarios. On one hand, the lack of concerted planning between interested parties could lead to inappropriate goals, inadequate objectives and management practices, higher environmental and social costs, scenario already forecasted (Pascual et al. 2007). On the other hand, cooperation and concerted planning among interested parties may in medium and long time scales, lead us to local and regional policies with clear goals and objectives, that could take into account conservation, sport fishery management and economic issues. Furthermore, concerted 
planning and research would help to avoid the replication of efforts as well as the implementation of counterpoised management practices in connected water bodies. As Pascual et al. (2009) stated, the effective management in Patagonia requires further research at community and ecosystem levels, but it also requires information about those who fish or otherwise benefit from fisheries management. Direct users such as fishermen, outfitters, and fishing guides have differing interest, motivations and sometimes conflicting views, which have to be taken into account (Malvestuto et al. 1983; Vigliano et al., 2000).Thus, a key component will be to focus research and management through greater cooperation among researchers, conservationists, direct and indirect resource users, and resource managers.

\section{REFERENCES}

Aigo, J; V Cussac; S Peris; S Ortubay; S Gómez; H López ET AL. 2008. Distribution of introduced and native fish in Patagonia (Argentina): patterns and changes in fish assemblages. Rev. Fish Biol. Fisheries, 18: 387-408.

ALLAN, JD \& AS FLECKER. 1993. Biodiversity conservation in running waters. BioSciences, 43: 32-43.

Archivos Oficiales del Ministerio de Agricultura y Ganadería de la República Argentina. Piscicultura Nahuel Huapi. S. C. Bariloche. Informes y correspondencia.

--. Piscicultura Nahuel Huapi. 1914-1917. S. C. Bariloche. Libro diario.

--. Piscicultura Bariloche. 1934-1979. S. C. Bariloche. Informes y correspondencia.

--. Piscicultura Bariloche. 1939-1942. S. C. Bariloche. Trabajos realizados, resumen mensual.

--. 1938-1979. S. C. Bariloche. Registro de siembras.

--. Piscicultura Río Limay. 1950-1979. S. C. Bariloche. Registro de siembras.

--. Centro de Salmonicultura Bariloche. 1971-1994. S. C. Bariloche. Informes y correspondencia.

Arratia, G; MB Peñafort \& S Menú-Marque. 1983. Peces de la región sureste de los Andes y sus probables relaciones biogeográficas actuales. Deserta, 7: 48-107.

BAIGÚN, CRM \& R Quirós. 1985. Introducción de peces exóticos en la República Argentina. Departamento de Aguas Continentales, Instituto Nacional de Investigación y Desarrollo Pesquero, Argentina. Informe Técnico $\mathrm{N}^{\circ}$ 2. Pp. 90.

BAIGÚN, C \& R FERRIz. 2003. Distribution patterns of native freshwater fishes in Patagonia, Argentina. Org. Divers. Evol.,3:151-159.

BAIZ, MdeL 1984. Informe sobre el estado de la acuicultura en la República Argentina. En: Pedini, F Criado, M. (eds). Informes nacionales sobre el desarrollo de la acuicultura en América Latina. FAO, Inf. Pesca, 294. 1: Pp. 138.

BesserA, EM. 2006. Los Parques Nacionales. In: Patagonia Total. Antártida e Islas Malvinas. Barcel Baires Ediciones S.A.-Alfa Centro Literario, Pp. 6.
BIANCO, PG. 1998. Freshwater fish transfers in Italy: history, local changes in fish fauna and on the future of native populations. In: Stocking and introduction of fish. Cowx, I G Oxford (eds). Fishing News Books, 167-185.

Blanco, G; E Cagigas; E Vázquez \& JA Sánchez. 1998. Genetic impact of the introduced domesticated strain of Brown trout, Salmo trutta, on native Spanish populations. In: Stocking and introduction of fish. Cowx, I. G. Oxford (eds). Fishing News Books, 371-379.

BRuno Videla, PH. 1938. Informe de las siembras efectuadas en C. Sarmiento, Chubut y estudios de las masas de agua apropiadas para el cultivo de salmónidos. Archivos oficiales del Ministerio de Agricultura y Ganadería de la República Argentina, 13pp.

Bruno Videla, PH. 1941. La pesca en el Parque Nacional Nahuel Huapi. Revista Médica Veterinaria, 23pp.

BRUnO Videla, PH. 1944. Algunos controles efectuados sobre peces existentes en la región de los lagos. Revista de la Facultad de Agronomía. y Veterinaria,11: 1-33.

BRUNO VIDELA, PH. 1978. Los salmónidos en Tierra del Fuego. Gobernación del Territorio Nacional de la Tierra del Fuego, Antártida e Islas del Atlántico Sud. Dirección de Intereses Marítimos, $44 \mathrm{pp}$.

Casalinuovo, MA; A Luizón; CA Sberna; PH Vigliano; PJ Macchi \& ME Lattuca. 2002. Recursos pesqueros recreacionales de Tierra del Fuego. Primera etapa: las poblaciones de salmónidos del río Ewan Sur. Informe Final. Consejo Federal de Inversiones, Pp. 233.

Colautti, RI. 2005. Are characteristics of introduced salmonid fishes biased by propagule pressure? Can. J. Fish.Aquat. Sci., 62: 950-959.

Correa, C \& MR Gross. 2007. Chinook salmon invades southern South America. Biol. Invasions, 10: 615-639.

Cussac, VE; E Habit; J. González; MA Battini; JP Barriga \& S CRICHIGNo. 2012. Los peces de agua dulce de la Patagonia: una puesta al día. Informe Técnico. INIBIOMA, ConicetUniversidad Nacional del Comahue. Pp. 13.

De Aparicio, FO \& HA Difrieri. 1958. La Argentina. Suma de geografía. Ed. Peuser, Bs. As. 2: Pp.444.

Dirección de Pesca Continental. Subsecretaría de Pesca y Acuicultura. Ministerio de Ganadería, Agricultura y Pesca, Argentina. 2011. Informe Nacional Sobre el Repoblamiento de Cuerpos de Agua Continentales. Pp 51.

DONALD, DB; RD VinERBROOKE; RS ANDERSON; J SYRGIANNIS \& MDGRAHAM. 2001. Recovery of zooplankton assemblages in mountain lakes from the effects of introduced sport fish. Can J. Fish.Aquat. Sci., 58: 1822-1830.

Drake, JM; P Baggenstos \& DM Lodge. 2005. Propagule pressure and persistence in experimental populations. Biol. Lett., 1: 480-483.

DunCAN, RP; TM BLACKBURn \& D Sol. 2003. The ecology of bird introductions. Annu. Rev. Ecol. Evol. S., 34: 71-98.

Elvira, B \& A Almodovar. 2001. Freshwater fish introductions in Spain: facts and figures at the beginning of the 21 st century. J. Fish Biol., 59: 323-331.

FAUCH, KD. 2008. A paradox of trout invasions in North America. Biol. Invasions, 10: 685-701.

Fukushima, M; N Takamura; L Sun; M Nakagawa; K Matsushige \& P XIEs. 1999. Changes in the plankton community following introduction of filter-feeding planktivorous fish. Freshwater Biol., 42: 719-735.

GonzÁles Regalado, T. 1941a. Informe de la campaña al Parque Nacional Lanín. Archivos oficiales del Ministerio de Agricultura y Ganadería de la República Argentina. Pp. 4. 
GonzÁles Regalado, T. 1941b. Informe de la campaña realizada a Junín de los Andes y alrededores. Archivos oficiales del Ministerio de Agricultura y Ganadería de la República Argentina. Pp. 6.

GonZÁles Regalado, T. 1941c. Informe de la campaña realizada en el río Limay desde Senillosa a Cipolletti. Archivos oficiales del Ministerio de Agricultura y Ganadería de la República Argentina. Pp. 4.

Gonzáles Regalado, T. 1945. Peces de los Parques Nacionales Nahuel Huapi, Lanín y Los Alerces. Anales del Museo de la Patagonia, 1: 121-138.

Gratwicke B \& BE Marshal. 2001. The relationship between the exotic predators Micropterus salmoides and Serranochromis robustus and native steam fishes in Zimbabwe. J. Fish Biol., 58: 68-75.

Habit, E; J GonzÁlez; DE Ruzzante \& SJ Walde. 2012. Native and introduced fish species richness in Chilean Patagonian lakes: inferences on invasion mechanisms using salmonid free lakes. Divers. Distrib.: 1-13. Doi: 10.1111/j.1472-4642.2012.00906.x.

HELFMAN, GS. 2007. Fish conservation: a guide to understanding and restoring global aquatic biodiversity and fishery resources. Island Press. Washington. Pp. 584.

Hershberger, PK; BK vander Leeuw; JL GregG; CA Grady; KM LUJAN et al. 2010. Amplification and transport of an endemic fish disease by an introduced species. Biol. Invasions, 12: 3665-3675.

HRABIK, HT; MP CAREY \& MS WEBSTER. 2001. Interactions between young-of-the-year exotic rainbow smelt and native yellow perch in a northern temperate lake. T. Am. Fish. Soc., 130: 130-568.

Juncos, R; D Milano; PJ Macchi; MF Alonso \& PH VIGLIANO. 2011. Response of rainbow trout to different food web structures in Northern Patagonia: Implications for growth, bioenergetics, and invasiveness. T. Am. Fish. Soc., 140: 415-428.

KOLAR, CS \& DM LODGE. 2001. Freshwaters nonindigenous species: iteractions with others global changes. In: Mooney, H. A. \& R. J. Hobbs (eds). Invasive species in a changing world. Island Press, Washington, D. C: 3-30.

KORSU, K \& A HousKO. 2009. Propagule pressure and initial dispersal as determinants of establishment success of brook trout (Salvelinus fontinalis, Mitchill 1814). Aquat. Invasions, 4: 619-626.

Korsu, K; A HousKo \& T MUOTKA. 2007. Niche characteristic explain the reciprocal invasion success of stream salmonids in differents continents. Proc. Natl. Acad. Sci. USA., 104: 9725-9729.

Krueger, CC \& B MAy. 1991. Ecological and genetic effects of salmonid introduction in North America. Can. J. Fish. Aquat. Sci., 48: 66-77.

KRUEGER, CC \& DJ DECJKER.1999. The process of fisheries management. In: CC Kohler and WA Hubert (eds). Inland Fisheries Management in North America. 2nd ed. American Fisheries Society, Bethesda, Maryland. 431-454.

LÓPEz, HL. 2001. Estudio y uso sustentable de la biota austral: Ictiofauna continental Argentina. Revista Cubana de Investigación Pesquera. Suplemento Especial. Pp. 35.

López, HL \& AM MiquelarenA. 2005. Biogeografía de los peces continentales de la Argentina. In: Llorente Bousquets J \& JJ Morrone (eds) Regionalización biogeográfica en Iberoamérica y tópicos afines. Red Iberoamericana de Biogeografía y entomología sistemática (RIBES XII.ICYTED), Mexico City. Pp. 42.
Lowe, S; M Browne; S Boudjelas \& M De PoOrter. 2004. Global Invasive Species Database. Publicado por el Grupo Especialista de Especies Invasoras (GEEI), Grupo Especialista de la Comisión de Supervivencia de Especies (CSE) de la Unión Mundial para la Naturaleza (UICN), www.issg.org/bookletS.pdf.

LYDEARD, Ch \& MC BELK. 1993. Management of indigenous fish species impacted by introduced mosquito fish an experimental approach. Southwest. Nat., 38: 370-373.

MACCHI, PJ; VE.CussaC; MF AlONSO \& MA DenEGRI. 1999. Predation relationships between introduced salmonids and the native fish fauna in lakes and reservoirs in northern Patagonia. Ecol. Freshwat. Fish, 8: 227-236.

Macchi, PJ; PH Vigliano; MA Pascual; MF Alonso; MA DENEGRI et al. 2008. Historical policy for fish management in Northern Continental Patagonia Argentina: A structuring force of actual fish assemblage? In: NIELSEN, J, J Dodson, K Friedland, T Hamon, N Hughes, J Musick \& E Verspoor (eds). Proceedings of the Fourth World Fisheries Congress: reconciling fisheries with conservation: the challenge of managing aquatic ecosystems. American Fisheries Society, Symposium, Bethesda, Maryland, 49: 331-348.

Malvestuto, SP. 1983. Sampling the recreational fishery. In: Nielsen, L., Johnson, D.R. (eds.), Fisheries Techniques Manual. American Fisheries Society, Bethesda, MD, USA, pp. 397-430.

McDowALL, RM. 2003. Impacts of introduced salmonids on native galaxiids in New Zealand upland streams: a new look at an old problem. T. Am. Fish. Soc., 132: 229-238.

McINTOSH, AR. 2000. Habitat and size-related variations in exotic trout impacts on native galaxiid fishes in New Zealand streams. Can. J. Fish. Aquat. Sci., 57: 2140-2151.

McIntosh, AR; CR Townsend \& TA CRowl. 1992. Competition for space between introduced brown trout (Salmo trutta L.) and a native galaxiid (Galaxias vulgaris Stokell) in New Zealand stream. New Zeal. J. Mar. Fresh., 13: 285-294.

Marchetti, MP. 1999. An experimental study of competition between the native Sacramento perch (Archoplites interruptus) and introduced bluegill (Lepomis macrochirus). Biol. Invasions,. 1: 55-65.

MARINI, TL. 1936. Los salmónidos en nuestro Parque Nacional de Nahuel Huapi. Anales de la Sociedad Científica Argentina, 121: 1-24.

MARINI, TL. 1944. Leyes, decretos, resoluciones y ordenanzas sobre pesca, caza mariìtima e industrializacioìn, recopiladas. Ministerio de Agricultura y Ganadería. Dirección Propaganda y Publicaciones. Publicación Miscelaneas, 164: Pp. 67.

Novillo, A \& RA OJEDA. 2008. The exotic mammals of Argentina. Biol. Invasions, 10: 1333-1344.

Ogutu-Ohwayo, R \& RE Hecky. 1991. Fish introductions in Africa and some of their implications. Can. J. Fish. Aquat. Sci., 48: 8-12.

Pascual, M; P Macchi; J URBAnSKI; F Marcos; C Riva Rossi et al. 2002. Evaluating potential effects of exotic freshwater fish from incomplete species presence-absence data. Biol. Invasions, 4: 101-113.

Pascual, MA; V Cussac; B Dyer; D Soto; P Vigliano et al. 2007. Freshwater fishes of Patagonia in the 21st Century after hundred years of human settlement, species introduction and environmental change. Aquat. Ecosyst. Health, 10: 212-227.

Pascual, MA; J Lancelotti; B Ernst Elizalde; JE Ciancio; 
E Aedo Marchant \& M Garcia Asorey. 2009. Scale, connectivity, and incentives in the introduction and management of nonnative species: the case of exotic salmonids of Patagonia. Front. Ecol. Environ.,7: 533-540.

PENCZACK, T. 1999. Impact of introduced brown trout on native fish communities in the Pilica River catchment (Poland). Environ. Biol. Fish. ,54: 237-252.

RINGUELET, RA. 1975. Zoogeografía y ecología de los peces de aguas continentales de la Argentina y consideraciones sobre las áreas ictiológicas de América del Sur. Ecosur2: 1-122.

Riva Rossi, CM; MA Pascual; E Aedo Marchant; N Basso; JE Ciancio; B Mezga et al. 2012. The invasion of Patagonia by Chinook salmon (Oncorhynchus tshawytscha): inferences from mitochondrial DNA patterns. Genetica, 140: 439-453.

RUESSINK, JL. 2005. Global Analysis of Factors Affecting the Outcome of Freshwater Fish Introductions. Conservation Biology, 19: 1883-1893.

SAunders, DL; JJ Meeuwig \& CJ Vincent. 2002. Freshwater protected areas: strategies for conservation. Conservation Biology, 16: 30-41.

SIMON, KS \& CR TOWNSEND. 2003. Impacts of freshwater invaders at different levels of ecological organization, with emphasis on salmonids and ecosystem consequences. Freshwater Biol., 48: 982-994.

Soto, D; I Arismendi; C Di Prinzio \& F Jara. 2007. Establishment of Chinook salmon (Oncorhynchus tshawytscha) in Pacific basins of Southern South America and its potential ecosystem implications. Rev. Chilena Hist. Nat., 80: 81-98

Thompson, FA. 1940. Salmonoid Fishes in the Argentine Andes. T. Am. Fish. Soc., 69: 279 - 284

Valette, L. 1924. Servicio de Piscicultura sus resultados hasta 1922 inclusive. Sección Propaganda e Informes. Ministerio de Agricultura de la Nación. Dirección General de Ganadería. Oficina de Pesca. Pp. 62.
Valiente, AG; F Ayllon; P Nuñez; F Juanes \& E GarciaVAZQUEZ. 2010. Not all lineages are equally invasive: genetic origin and life-history in Atlantic salmon and brown trout acclimated to the Southern Hemisphere. Biol. Invasions, 12: 3485-3495.

Vigliano, PH; G Lippolt; A Denegri; M Alonso; P Macchi \& C Odyle Dye. 2000. The human factor of the sport and recreational fishery of San Carlos de Bariloche, Río Negro, Argentina. Fish. Res., 49:141-153.

Vigliano, PH \& MF Alonso. 2007. Salmonid Introductions in Patagonia: a mixed blessing. In: Bert, TM (ed.). Ecological and Genetic Implications of Aquaculture Activities. Nordstadt, The Netherlands. 315-331.

VolPe, JP; BR AnHolt \& BW Glicknan. 2001. Competition among juvenile Atlantic salmon (Salmo salar) and steelhead (Oncorhynchus mykiss): relevance to invasion potential in British Columbia. Can. J. Fish. Aquat. Sci., 58: 197-207.

WELCOMME, RL. 1988. International introductions of inland aquatic species. FAO Fisheries Technical Paper $N^{\circ}$ 294. Pp. 318.

Welcomme, RL. 1992. A history of international introductions of inland aquatic species. ICES (International Council for Exploitation of the Sea) Marine Science Symposium, 194: 3-14.

Wegrzyn, D \& S Ortubay. 2009. Salmónidos en Patagonia. Volumen I. Bariloche, Argentina. Pp. 164.

Willis, B. 1988. "El Norte de la Patagonia". Tomo 1: Naturaleza y Riquezas. Buenos Aires. Eudeba, Pp. 326.

Witte, F; T Goldschmidt; PC GoudswaARd; W Ligtvoet; MPJ VAN OIJEN \& JH WaninK. 1992. Species extintions and concomitant ecological changes in Lake Victoria. Neth. J. Zool., 42: 214-232.

Young, KA; JB Dunham; JF Stephenson; A Terreau; AF THAILLY et al. 2010. A trial of two trouts: comparing the impacts of rainbow and brown trout on a native galaxiid. Anim. Conserv., 13: 399-410. 